\title{
Düğün Yeri Seçimine Etki Eden Kriterler ve Düğünlerin Yerel Ekonomiye Katkısı: Hatay İli Örneği
}

\section{Criteria Affecting of Wedding Location and Contribution of Weddings to Local Economy: Case of Hatay}

\author{
Halil SUNAR, Giresun Üniversitesi, Türkiye, halil.sunar@windowslive.com \\ Orcid No: 0000-0002-5131-4056 \\ Balhun ERSÖZ, Mersin Üniversitesi, Türkiye, ersozbalhun@gmail.com \\ Orcid No: 0000-0002-0044-8169
}

\begin{abstract}
Öz: II. Dünya Savaşı sonrasından günümüze kadar olan süreçte Dünya genelinde her yıl turizm aktivitelerine katılan kişi sayısı artmıştır. Artan katılım ile birlikte büyüyen küresel turizm ekonomisinden daha büyük paylar almak isteyen ülkelerin turizm alanında planlamalar ve stratejiler geliştirmesi kaçınılmaz olmuştur. Bu araştırma, düğün turizmi kapsamında evlenen bireylerin düğün yeri seçimini etki eden kriterleri, dügün turizminin arz unsurlarından biri olan düğ̈̈n sağlayıcıları tarafindan belirlemeyi amaçlamaktadır. Araștırma ile Hatay'ın düğün turizmi kapsamında düğün yeri seçimini etkileyen kriterler, en çok karşılaşılan sorunlar, düğün turizmi algıları, Hatay’da düğün pazarının durumu ve önerileri hakkında bilgi edinilmeye çalışılmıştır. Araştırma yöntemi olarak gözlem ve mülakat yöntemi birlikte kullanılmıştır. Gözlemler düğ̈̈n etkinliğinin gerçekleştirildiği düğün salonu, konaklama isletmesi vb. yerlerde gerçeklestirilmistir. Mülakatlar 28 düğün salonu sahipleri/yöneticileri, 8 düğün organizatörü, 11 konaklama işletmesi sahibi/yöneticisi, 14 seyahat acentası sahibi/yetkilisi olmak üzere toplamda 61 kişi ile gerçekleştirilmiştir. Yarı yapılandırılmış mülakat yöntemi kullanılarak düğün organizasyonları ile doğrudan ve dolayl ilgilisi olan kişiler ile gerçekleștirilmiștir. Gözlem ve mülakatlardan elde edilen sonuçlar sistematik bir șekilde derlenerek karșılaștırmalar yapılmıs ve çarpıcı olarak ön plana çıkan bulgular yorumlanmıștır. Araștırmada sonuç olarak Hatay'ın etnik ve kültürel yapısından dolayı birçok kültüre ev sahipliği yapması çok farkl inanışlardaki birçok dügün geleneğinin günümüze kadar devam etmesini sağlamıstır. Ayrıca Hatay'daki nüfusun belli bir bölümü Umman, Arabistan, Libya, Iran, Irak ve Katar gibi ülkelerde çalışmaya gitmeleri ve/veya orada akrabalarının olması, bu kişilerin düğünlerini Hatay'da yapıyor olması veya Hatay'lı biriyle evlenmeleri düğ̈̈n turizmi açısından Arap ülkeleri önemli bir pazarı oluşturduğu sonucuna ulaşılmıştır.
\end{abstract}

Anahtar Sözcükler: Turistik Ürün Çeşitlendirmesi, Dügün Turizmi, Düğ̈̈n Turisti, Hatay

Abstract: Since the end of World War II, the number of people participating in tourism activities has increased every year throughout the world. With increasing participation, it is inevitable for countries that want to take a bigger share from the growing global tourism economy and develop plans and strategies in the field of tourism. The aim of this study is to determine the criteria that affect the choice of wedding place by the wedding providers who are one of the supply elements of wedding tourism. With this research, it was tried to obtain information about the criteria affecting the choice of wedding venue, the most encountered problems, perceptions of wedding tourism, the status of the wedding market in Hatay and the suggestions. Observation and interview methods were used together as research method. Observations of the wedding event where the wedding hall, accommodation business, etc. places. The interviews were conducted with a total of 61 people including 28 wedding hall owners / managers, 8 wedding organizers, 11 accommodation business owners / managers and 14 travel agency owners / officials. Semi-structured interviews were conducted with individuals directly and indirectly involved in wedding organizations. The results obtained from the observations and interviews were systematically compiled and compared, and strikingly interpreted findings were interpreted. As a result of this research, Hatay's hosting of many cultures due to its ethnic and cultural structure has enabled many wedding traditions with different beliefs to continue until today. In addition, a certain part of the population in Hatay, Oman, Arabia, Libya, Iran, Iraq and Qatar to work in countries such as and / or relatives there, the wedding of these people in Hatay or marry someone from Hatay in terms of wedding tourism important Arab countries It was concluded that it constitutes a market.

Keywords: Touristic Product Diversification, Wedding Tourism, Wedding Tourists, Hatay

\section{Giriş}

Hizmet sektörlerinden biri olan turizm sektörü ülke ekonomilerine sağladığı faydalar göz önünde bulundurulduğunda, ülkelerin mevcut potansiyellerini korumak ve bütüncül çözüm arayışları çerçevesindeki katkısı nedeniyle önemli bir sektör durumundadır. Dünya Turizm Örgütü 2019 yılında yayınladığı turizm raporunda insanların eşsiz deneyimler ve değişim arzusu, gastronomi, sağlık, macera, lüks, yalnız seyahat gibi nedenlerden dolayı seyahatler gerçekleștirdiğini belirtmiștir. Dünya Turizm Örgütü Ocak 2019 verilerine göre dünya geneli turizm aktivitelerine katılan kiși sayısı yaklaşık olarak 1,4 milyara ulaşmış ve bu rakam 2 yıl öncesine göre $\% 6$ artış göstermiştir. Aynı zamanda turizm sektörü dünya genelinde 1,7 trilyon ABD doları ekonomik büyüklüğe sahip olması ve bu rakamın günde yaklaşık olarak 5 milyar ABD dolarına denk gelmesi nedeniyle ülkeler açısından önem arz etmektedir. Ülkeler bu pastadan daha fazla pay alabilmek için, rekabet avantajı sağlayabilecek planlamalar yapmakta ve stratejiler geliştirmektedirler (Kiper, 2006: 1). Bu stratejilerden birisi de turistik ürün çeşitlendirmesidir. Özellikle kitle iletişim araçlarında yaşanan gelişmeler insanların bilgiye kolay ulaşmasını sağlamış ve bunun neticesinde tüketici konumunda olan ziyaretçiler gidecekleri yerleri öncesinde

Makale Gecmiși / Article History 
kalite, fiyat vb. özellikleri hakkında bilgi sahibi olabilmek amacıyla araştırmalar yapmakta ve karşılaştırmalar yaparak kendi ihtiyaç ve beklentilerine en uygun yeri tercih etmektedirler. Bu durum talep açısından fayda sağlamakta iken arz açısından bakıldığında bir destinasyonu popüler hale getirebileceği gibi yaşanabilecek olumsuzluklar sonucunda destinasyonu dibe de çekebilmektedir.

Yapılan bu araştırmanın konusunu turizm türlerinden olan ve önemli bir pazar payı olan düğün turizminin yerel ekonomiye katkısı ve düğün turizmi kapsamında evlenen bireylerin düğün yeri seçimini etki eden kriterleri, düğün turizminin arz unsurlarından biri olan düğün sağlayıcıları oluşturmaktadır. Alan yazında böyle bir çalışma olmaması konunun önemini artırmaktadır.

\section{Düğün Turizmi ve Gelişimi}

Evlilik, kutlamaları kültürden kültüre farklılık gösteren pek çok etnik ve dini gelenekle gerçekleşmektedir. Küreselleşmenin etkisiyle bazı kültürel etkinlikler kaybolabildiği gibi, bazı kültürler birbirinden etkilenebilmekte ve bazı kültürler atalarının geleneklerine göre kutlanma yapmaya devam etmektedirler. Düğünler birer kültürel olgu ve etkinlik olmasından dolayı düğün turizminin sınırlarını belirlemeyi güçleştirmektedir. Düğün turizmi kavramı, dünya çapında çiftlerin genellikle evlenmek ya da dügüunlerini kutlamak için yurtdışına seyahatlerini içeren bir niş pazar olarak ifade edilmektedir (Rogerson, 2015: 3-4). Getz (2005) düğün turizmini bir etkinlik turizmi türü olarak ele almıştır. Bunun nedeni etkinlik turizmini olayların tüm potansiyel ekonomik faydalarını gerçekleştirmek için bir varış noktası geliştirme ve pazarlama stratejisi olarak tanımlamasıdır (Getz, 2008: 404-405). Getz’e göre ayrıca özel etkinliklerin kitleler için değil, bireyler, aileler ve sosyal gruplar için düzenlendiğini ifade etmiştir. Günümüzde dügün turizmi adı altında yapılan turizm faaliyetlerinin büyük bir bölümünü balayı seyahatleri oluşturmaktadır (Seebaluck vd., 2015). Alan yazında düğün turizmi kavramı ile ilgili yapılan tanımlamaları eksik olarak ifade eden ve en geniş tanımlamayı Vidauskaite (2015) tarafından yapılmıştır. Bu tanımlamaya göre düğün turizmi; düğün turizminin temelini oluşturan balayının da içinde yer aldığı, çiftin ikamet edilen yerde yapılsa bile katılımcıların başka yerlerden gelebileceğini göz önünde bulundurularak düğ̈̈n turizmini evlenmeyi veya düğ̈nü kutlamayı amaçlayan çiftlerin ve katılımcıların yurt içi veya yurt dışı seyahatlerinin bütünü olarak tanımlamıştır. Düğün turizminin temelini oluşturan balayı seyahatleri ise, turizm sektöründe önemli bir pazarı oluşturduğu gibi bir hafta ile bir aya kadar süren yeni evli çiftlerin, evlenmelerini kutlamak için düğün töreninden hemen sonra yaptıkları seyahatler olarak ifade edilmektedir (Moira vd., 2011; Winchester vd., 2011). Düğün turizmi gelişiminin nedenleri ise aşağıdaki gibi sıralanmaktadır (Vidauskaite, 2015: 5-6):

- Dügün maliyetlerini düşürmek (daha az kişinin katılımı, balayı ile birleştirme, alternatifleri değerlendirme vb.)

- Çiftlerin eşsiz, egzotik ve akılda kalıcı ortamlarda evlenme arzusu,

- $\quad$ Dini evlilik törenlerinin azalması ve ikinci veya üçüncü kez evlilikler,

- Bazı ülkelerde eş cinsel evliliklerin yasal olması,

- Ulaşım sektöründeki gelişmeler neticesinde rekabetin artmasıyla fiyatların azalması,

- Evlilikle ilgili prosedürlerde yapılan düzenleme ile kolay hale gelmesidir.

Düğün turisti kavramı, evlenmek veya bir akraba, arkadaş, tanıdık düğününe katılmak için seyahat eden kişi olarak ifade edilmektedir (Bertella vd., 2017: 4). Düğün turizmine katılan turistler ilk defa evlenenler, birden fazla kez evlenenler, evliliklerini yenileyenler, eş cinsel evlilikler, evliliklere tanıklık eden katılımcılar olmak üzere beş grupta toplanmıştır (Major vd., 2010: 252; Vidauskaite, 2015: 17-18). Düğünü yapacak olan çiftlerin yerine düğün destinasyonları veya organizatörleri tarafından yapılan hizmetler (Khodzhaeva, 2016: 10-11; Ersöz, 2019: 55):

- Yapılacak olan düğün etkinliğinin tasarlanması,

- $\quad$ Evlenecek olan çiftin bütçelerine göre istedikleri düğünün hazırlı̆̆g,

- Uygun ortamın oluşturulması,

Ayrıntılı kontrol listesi planlanması,

- Katılımcı listesinin hazırlanması ve iletişim sağlanması,

- Etkinliğin gerçekleştirileceği yerin (oteller, düğün malikâne vb.) belirlenmesi,

- Dügün ile ilgili servis sağlayıcılarının (fotoğrafçılar, güzellik uzmanları, çiçekçiler, tatlı, pasta vb. hizmet verenler) belirlenmesi, sözleşmelerin hazırlanması ve yürütülmesi,

- Seyahat haritası gibi özelleştirilmiş dekorasyonların tedarik edilmesi;

- Dügün gününde hizmetlerin koordinasyonu;

- Oluşabilecek herhangi bir sorun halinde alternatif bir planın oluşturulması,

- $\quad$ Resmi evrak işleridir (yurt dışı ise, sigorta, vize vb. işlemler). 


\section{Düğünlerin Yerel Ekonomiye Olan Katkıları}

Bireylerin farklı deneyimler yaşama isteğinin yanı sıra; düşük maliyetler, rekabetçi paketler, doğal güzellikler, uluslararası uçuşların artması ve tüketici alışkanlıklarındaki değişiklikler nedeniyle farklı destinasyonlarda düğün yapmaktadırlar. Düğün turizminin destinasyona doğrudan ve dolaylı olarak sağladığı birçok olumlu katkısı bulunmaktadır (Kim ve Kim, 2013). Bu katkılar:

- Organizasyon şirketleri, seyahat acentalarına yeni iş kolları,

- Konaklama işletmelerinin mevsimsellik özelliğinin ortadan kaldırılması veya sezonun uzatılmasına sağladığı katk1,

- Destinasyonun bilinirliğine sağladığı katkı,

- $\quad$ Ülke imajına ve tanıtımına sağladığı katkı,

- Destinasyonun kalkınmasına sağladı̆̆ı katkı,

- Destinasyonun ulaşım gibi alt yapı eksikliklerinin giderilmesine sağladığı katkı,

- Düğün organizasyonu ile destinasyonda istihdama sağladığı katkı,

Düğün ile ilgili dolaylı olarak düğün fotoğrafçısı, çiçekçiler, konaklama işletmeleri, video çekimi, araç kiralama, ikramlar, gelinlik damatlık satıcıları veya üretim yapan tuhafiyeler, kuaför gibi yan hizmetlere sağladığı ekonomik yönde önemli katkılardır. 2014 yılı içerisinde dünya geneli yapılan düğünlerin yaklaşık \%15'inin destinasyon düğünlerinden oluşturduğu tahmin edilmektedir. Mintel'e göre (2010), Birleşik Krallık'ta, her beş düğünden biri yurtdışında gerçekleşmekte ve bu durum her yıl yaklaşık olarak \%27'lik bir artış göstermektedir. Düğün turizmi destinasyonunda düğüne katılan misafir sayısı, düğün masraflarını ve ulaşım, konaklama, yemek veya kiralama hizmetlerine harcanan maliyet değerlerini artırarak ev sahibi destinasyona ekonomik olarak değer katmaktadır. Kim ve Agrusa (2005) çalışmalarında benzersiz ve unutulmaz bir deneyim yaşamak istemelerinden dolayı düğün turistlerinin tipik tatilcilere göre daha fazla harcama yaptıklarını belirtmişlerdir. Düğün turizminin oluşturduğu bu talebin tamamı ile birlikte, bu sektöre ihtiyaç duyulan tüm hizmetleri sağlayacak yeni iş kolları oluşturmakta ve böylece yerel ekonomilerin kalkınması açısından oldukça önem arz etmektedir.

\section{Araştırmanın Yöntemi}

$\mathrm{Bu}$ araştırmada düğün turizmi kapsamında evlenen bireylerin düğün yeri seçimini etki eden kriterleri, düğün turizminin arz unsurlarından biri olan dügüun sağlayıcıları tarafından belirlenmesini amaçlamaktadır. Çalışma ile Hatay’ın düğün turizmi potansiyeli, mevcut durumu, düğün etkinlikleri yapısı, ekonomik boyutu gibi unsurları irdelemektedir. Araştırma alanı olarak Hatay’ın tercih edilmesinin nedeni etnik ve kültürel yapısından dolayı birçok kültüre ev sahipliği yapması ve bu durumun çok farklı inanışlardaki birçok düğün geleneğinin günümüzde de devam etmesidir. Ayrıca dünya genelinde önemli düğün destinasyonları arasında popüleritesi yüksek olan Kıbrıs'a yakın olması nedeniyle rekabet edebilecek potansiyeli olmasından dolayı araştırma alanı olarak Hatay tercih edilmiştir. Araştırma yöntemi olarak gözlem ve mülakat yöntemi birlikte kullanılmıştır. Gözlem, belirli bir kimse, yer, olay, nesne, durum ve şarta ait bilgi toplamak amacıyla belirli hedeflere yöneltilmiş bir bakış veya dinleyiş olarak ifade edilmektedir (Özsoy, 1970: 36). Gözlemler düğün etkinliğinin gerçekleştirildiği düğün salonu, konaklama işletmesi vb. yerlerde gerçekleştirilmiştir. Mülakat, en basit ifadeyle bir konu hakkında ilgili kişilerden sorulacak sorular çerçevesinde veri toplama tekniği olarak ifade edilmektedir (Karasar, 2005: 165; Aziz, 2011: 85). Mülakatlar, düğün organizasyonları ile doğrudan ve dolaylı ilgilisi olan kişiler ile gerçekleştirilmiştir. Görüşmeler sırasında önceden hazırlanan sorulara cevap aranırken, görüşme yapılan kişininin araştırma ile alakalı sorular dışındaki anlatımlarına olanak sağlanarak mülakatta yer verilmeyen konular hakkında da veri toplanmıştır. 28 düğün salonu sahipleri/yöneticileri, 8 düğün organizatörü, 11 konaklama işletmesi sahibi/yöneticisi, 14 seyahat acentası sahibi/yetkilisi olmak üzere toplamda 61 kişi ile mülakat yapılmıştır. Mülakat yapılacak olan kişiler, kuruluşlar 2018 yılı TUİK'te yer alan Hatay'daki evlenme istatistikleri doğrultusunda, Hatay'ın 15 olan ilçesinin evlilik yoğunluklarına göre belirlenmiş ve bütün ilçelerden yetkililerle mülakatlar gerçekleştirilmiştir. Araştırma aracı olarak not alma tekniği kullanılmıştır. Elde edilen bulgular sistematik bir şekilde raporlanarak karşılaştırma yapılmıştır.

\section{Bulgular}

Araştırmanın belirlenen amacı doğrultusunda Hatay'da evlenen bireylerin düğün yeri seçimini etki eden kriterleri belirlemeye yönelik mülakatlar ve gözlemler gerçekleştirilmiştir. Yapılan mülakatlarda düğ̈n yeri seçimini etkileyen kriterler, en çok karşılaşılan sorunlar, düğün turizmi algıları, Hatay’da düğün pazarının durumu ve önerileri hakkında bilgi edinilmeye çalışılmıştır. Düğün organizatörleri, düğün salonları, konaklama işletmeleri, seyahat acentaları ile gerçekleştirilen mülakatlardan ve gözlemlerden elde edilen bulgular ayrı ayrı değerlendirilmiştir.

\subsection{Düğ̈̈n Salonları Sahipleri/Yöneticileriyle Gerçekleştirilen Mülakatlardan Elde Edilen Bulgular}


Toplamda 17 düğün salonu sahibi ve 11 düğün salonu yöneticisi olmak üzere toplamda 28 kişi ile mülakat gerçekleştirilmiştir. Düğün salonu kiralanırken çiftler genellikle aileleriyle birlikte gelmektedirler. Geçmiş yıllarda birçok kişi yaklaşık 1 yıl öncesinden salonu kiralarken günümüzde bu durum çok nadir şekilde karşımıza çıkmaktadır. İnsanların salon kiralarken en fazla dikkat ettikleri fiyat ve fiyata dâhil olan hizmetler ön plana çıkmaktadır. Düğün salonlarında genel olarak verilen hizmetler; pasta, meşrubat, çerez vb. ikramlar, anlaşmalı fotoğrafçı ve kameramanlar, bay-bayan kuaförü, araç süsleme, araç hizmeti ve canlı müzik hizmeti verilmektedir. Görüşülen 28 düğün salonundan sadece 6'sı yemekli dügün etkinliği yapmaktadır. Düğün salonlarının birçoğu vermiş oldukları bu hizmetlerin dışında çiftlerin ve ailelerinin talepleri doğrultusunda ek hizmet verebilmekte veya düğün salonunun izni doğrultusunda kendi ihtiyaçlarını karşılayabildiklerini belirtmişlerdir. Çoğu düğün salonunda standart içerik küçük farklılıkların dışında aynıdır. Fiyatlar genel olarak 300- 400 kişi gibi 100’er 100'er artmakta veya düğün salonunun büyüklüğüne göre 300- 500 - 700 kişilik olarak büyük rakamlara göre fiyat verilmektedir. Ayrıca tanıdık, eş, dost vb. aracılar ile indirim yapılması isteği en çok karşılaştıkları durum olduklarını belirtmişlerdir. Düğün salonlarının 7'si düğün sözleşmesi veya hizmet sözleşmesi imzalarken, 4'ü senet imzalamakta, 17'si sözleşme imzalamamaktadır. Ayrıca düğün salonlarını genellikle orta gelir düzeyi ve altındaki olan aileler tercih ettiklerini belirtmişlerdir. Ödeme genellikle bir miktar kaparo veya yarısını peşin olarak alınmakta, geri kalanı ise düğün günü tahsil edildiğini belirtmişlerdir. Ayrıca kış aylarında yoğun olmadıklarından dolayı fiyatların daha uygun olduğunu belirtmişlerdir.

Görüşülen kişiler düğün salonunu tercih edenlerin genellikle kalabalık aileler olduğunu belirtmişlerdir. Görüşülen 28 düğün salonundan 3 düğün salonu dışında önceden rezervasyon, kişi listesi, oturma düzeni gibi hizmetlerin olmadığını ve bunun tamamen düğün sahiplerinin elinde olduğunu belirtmişlerdir. İstisna olarak bazı aileler gelin ve damat masasının olduğu yerin çevresine birinci derece aile fertlerine ayrıldığını belirtmişlerdir. Bazı düğün salonları ayrıca davetiye oluşturma, gelinlik kiralama, damatlık kiralama gibi hizmetleri de ekstra olarak sunduklarını belirtmişlerdir. Düğün salonlarının iletişim içinde oldukları işletmeler olarak; çiçekçiler, pastane, yiyecek-içecek işletmeleri (meşrubat, çerez vb.), fotoğraf ve video çekimi yapan işletmeler, araç kiralama işletmeleri olarak belirtmişlerdir. Mülakat yapılan 28 işletmeden 4 işletme aynı zamanda organizasyon şirketleriyle birlikte çalıştığını belirtmiş ve yalnızca 1 düğün salonunun web sitesi bulunmaktadır.

Düğün salonlarının en çok karşılaştıkları sorunlar ise, fotografçılar ile çift ve çiftin ailesi arasında sorun yaşanmaktadır. Bu durumun nedeni olarak ise, her yıl yerel bir firma ile yıllık anlaşma imzalandığı için belirli sayıda poz ve video kaydını fiyata dâhil olması, dışarıdan başka fotografçı getirme isteği gibi sorunların oluştuğunu belirtmişlerdir. Bazı düğün salonları sözleşme yapmamalarına rağmen fotoğraf firması sözleşme imzalattığını belirtmişlerdir. Düğün salonu açmanın zor olmadığını bununla ilgili yasal düzenlemelerin yeterli olmadığını, sadece sermaye gerektirdiğini belirterek düğün turizmi ile ilgili olarak düğün salonlarının yeterli alt yapılarının bulunmadığı, kalifiye yabancı dil bilen iş görenlerin olmadığını, düğün turizmi faaliyetlerinin daha çok otel işletmeleri ve kır düğünü yapan, deniz kenarı veya doğal manzarası olan yerlerde uygulanmasının daha verimli olacağını belirtmişlerdir.

\subsection{Düğ̈̈̈n Organizatörleriyle Gerçekleştirilen Mülakatlardan Elde Edilen Bulgular}

Toplamda 8 düğün organizasyonu yapan firma ile mülakat gerçekleştirilmiştir. Düğün organizatörleri genellikle çalışan çiftlere veya başka yerden gelmiş Hatay’a yerleşmiş fazla çevresi olmayan bireylere hizmet verdiklerini belirtmişlerdir. Ayrıca Hatay'da organizasyon olarak büyük olan otel işletmelerine de danışmanlık yaptıklarını belirtmişlerdir. Düğün organizatörleri düğün sahiplerinin kendilerini tercih etmelerinin nedenleri olarak, sorumluluklarını hafifletmek, alternatifler sunmak, istek ve görüşlerine göre etkinliği düzenlemek ve stresin olmadığı öncesinde ve sonrasında bir düğün gerçekleştirme istekleri olduğunu belirtmişlerdir. Konseptleri oluştururken her ne kadar modayı takip etseler de, malzemelerin maliyetinin yüksek olması nedeniyle yenilemeleri 2 ile 3 yıl arasında yenilediklerini ve diğer düğün organizatörleri, otel işletmeleriyle sürekli iletişim halinde olduklarını ve birbirleri arasında malzemeleri kiraladıklarını belirtmişlerdir. Ayrıca düğün organizatörleri düğün sözleşmesi imzaladıklarını belirtmişlerdir. Düğün organizasyonları dışında en çok yaptıkları iş olarak, kına gecesi, nişan, evlenme teklifi, doğum günleri, yıl dönümleri ve kır düğünleri, dış çekimler, gelin odası ve düğünün öncesi ve sonrasını kapsayan düğün hikâyesi çekimleri organize ettiklerini belirtmişlerdir. Kendilerinden hizmet alan kişilerin istisnalar haricinde kadınların, 25 ile 35 yaş aralığında, erkekler ise, 25 ile 40 yaş arasında olduğunu belirtmişlerdir. Düğün organizatörleri genel olarak çiftlerin yalnız geldiklerini ve ilk etapta kendilerinin tasarladıklarının aynısı veya ona yakın bir düğün oluşturmaya çalıştıklarını ve genel olarak kararların büyük bir bölümün kadınların karar verdiklerini belirtmişlerdir. Çiftlerin düğün organizatörlerini seçmelerinin başka bir nedeni ise; gerek pasta kesimi sırasında olsun, gerek kameraman ve fotografçılar, gerekse çalışanların düğün bitiminde bahşiş istemesi veya bu tarz konuşmalara maruz kalması ve insanların bu tarz şeylerle uğraşmak istememesi olduğunu belirtmişlerdir. Düğün organizatörlerinin tamamı web siteleri olduklarını belirtmişlerdir. Düğün turizmi konusunda ise, düğün salonları ile ilgili olarak iç pazarda önemli bir yere sahip olduklarını fakat dış pazar olarak bakıldığında yapılabilecek önemli teşvik ve yasal düzenlemeler ile Hatay’ın kültürel birikimi sayesinde gerekli yatırımlar ve tanıtım çalışmaları yapıldığında önemli bir düğün destinasyonu olabileceğini belirtmişlerdir.

\subsection{Konaklama İşletmeleriyle Gerçekleştirilen Mülakatlardan Elde Edilen Bulgular}

Toplamda düğün etkinliği yapan 11 konaklama işletmesi ile mülakat gerçekleştirilmiştir. Konaklama işletmelerinde düğün etkinliklerinde yapılan fiyatlandırma genellikle kişi başı üzerinden ve düğünün içeriklerine göre yapılmaktadır. 
Genel olarak insanlarda otellerde düğün yapmanın pahalı olduğu algısının bulunduğunu ama bu durumun yanlış olduğunu belirtmişlerdir. Konaklama işletmelerinde yaz sezonunda düğün yapmanın fiyat olarak kış sezonuna göre daha uygun olduğunu belirtmişlerdir. Bu durumun nedeni olarak ise, yaz aylarında konaklama işletmesi yoğun olduğundan dolay1 yarım pansiyon hizmet verdiklerini ve istihdam edilen kişi sayısının fazla olduğunu fakat kış aylarında oda-kahvaltı hizmeti verdiklerini özellikle yemekli düğünlerde mutfağın açılması, etkinliğin büyüklüğüne göre ekstracı olarak isimlendirilen personel çalıştırılması gibi nedenlerden dolayı kış aylarında düğünlerin daha pahalı olduğunu belirtmişlerdir. Otellerde düğünler minimum 100 kişi olmakta ve gelin odası kuaför gibi hizmetlerde sunduklarını belirtmişlerdir. Konaklama işletmelerini tercih eden çiftlerin genellikle orta düzey ve üzerinde gelir düzeyine sahip olan kişiler olduğunu belirtmişlerdir. Özellikle İskenderun, Samandağ ve Arsuz İlçelerinde yer alan konaklama işletmeleri diş çekim gibi hizmetler vermekte, organizasyon şirketleri ile de iş birliği yapmakta ve balayı odası da sattıklarını belirtmektedirler. Hizmet verdikleri kişilerin genellikle bankacı, öğretmen, kamu görevlisi, Hatay'ın önde gelen zenginlerinden oluştuğunu belirtmiştir. Yemekli düğünlerde genellikle düğün tarihinden 2 gün öncesine kadar konukların rezervasyon yaptırarak net sayı belirlenmekte ve oturma düzeni düğün sahipleri tarafindan planlandığını belirtmişlerdir. Çiftlerin bizi tercih etmelerinin en önemli nedenlerinden birisi de şehir dışından gelenlerin otelde konaklaması ve düğün sahiplerinin bu konuklarla ilgilenme sorumluluklarını hafifletmek olduğunu belirtmişlerdir. Düğün turizmi ile ilgili olarak, konaklama işletmeleri gerekli yasal düzenlemelerin yapılması özellikle Hatay’ın Arap bir nüfusa sahip olmasından dolayı Arap kültürüne yabancılık çekmeyeceği ve Arap pazarına yönelmesi gerektiğini, Arap ülkelerinde tanıtım ve reklam çalışmaları yapıldığı takdirde önemli bir düğün destinasyonu olacağını belirtmişlerdir. Ayrıca düğünlerin konaklama işletmesi açısından sezonu uzatıcı etkisi olduğunu belirtmişlerdir.

\subsection{Seyahat Acentalarıyla Gerçekleştirilen Mülakatlardan Elde Edilen Bulgular}

Toplamda 14 seyahat acentası ile mülakat gerçekleştirilmiştir. Günümüzde artık internetin yaygınlaşmasıyla insanlar pek çok ihtiyacını internet ortamında araştırarak kendilerine en uygun olan ürünleri satın aldıklarını belirtmişlerdir. Balayı için gelen çiftlerin önceden bir fiyat araştırması yaparak geldiklerini, özellikle büyük acenta ve tur operatörleri şubelerinden indirim olup olmayacağını, kendilerinden fiyat alarak karşılaştırma yapıp karar verdiklerini belirtmektedirler. Genellikle 45 yaş ve üzeri çiftler balayı, yıldönümü gibi özel günlerinde tatile gitmek isteyen kişiler acentaların düğün turizmi ile ilgili müşteri profilini oluşturduğunu belirtmişlerdir. Bu kişiler yoğun olarak çalışan ve interneti çok etkin bir şekilde kullanmadıkları için ve genellikle uğraşmamak, acentayı kendilerine garanti olarak gördüklerini belirtmişlerdir. Acenta yetkilileri düğün turizmi adı altında faaliyetlerde bulunmak istediklerini fakat malzeme maliyetlerinin yüksek olması, aracılık yaptıkları takdirde konaklama işletmelerinin ve organizasyon işleriyle uğraşanların zaten bu işi yaptıklarından dolayı devre dışı kalmalarına neden olabileceğini, acentaların artık internet ortamına taşındığı ve düğün turizminin acentalar için hayati bir dönüm noktası olabileceğini, bununla ilgili yasal düzenlemelerin ve denetimlerin gerektiğini belirtmişlerdir. Hatay’da Arap kökenli nüfusun fazla olmasından ve şehrin farklı inanç ve kültürleri barındırması düğün turizmine çabuk adapte edilebileceğini ve özellikle Arap pazarına yönelik çalışmalar yapılması gerektiğini belirtmişlerdir.

\subsection{Gözlemlerden Elde Edilen Bulgular}

Düğün salonlarında genellikle adet yerini bulsun amaçlı düşük fiyat seviyesinde düğünler yapılmakta ve düğün salonları gelişime kapalı standart piyasa şartlarına göre hizmet verdikleri gözlemlenmiştir. Düğün salonlarını işletenlerin turizmci olmadığı yatırım amaçlı ve karlı bir iş olduğu için bu sektöre yöneldiği gözlemlenmiştir. Organizasyon şirketleri ve konaklama işletmeleri ile yapılan görüşmelerde Hatay’da bu konuda eksiklikler olduğu ve en önemli eksikliğin bir standart kuralların ve denetimin olmaması gözlemlenmiştir. Organizasyon şirketleri açısından bakıldı ğında maliyetlerin yüksek olması, talebin sınırlı düzeyde kalmış olması organizasyon şirketlerinin gelişimindeki en önemli engel olarak görülmektedir. Organizasyon şirketleri genel olarak Hatay’a sonradan yerleşen kişiler müşteri gruplarını oluşturmakta ve bu kişiler genellikle çalışan kişilerden oluştuğu için sorumluluklarını azaltmak amacıyla tercih ettikleri ve düğün organizasyonlarının katılımcı olarak küçük sayılar olduğu gözlemlenmiştir. Konaklama işletmeleri ile organizasyon işletmelerinin birçoğu aralarında anlaşma olduğu ve birçok konuda birbirlerine destek oldukları gözlemlenmiştir.

\section{Sonuç ve Öneriler}

$\mathrm{Bu}$ araştırma, düğünlerin yerel ekononiye katkısı ve düğün turizmi kapsamında evlenen bireylerin düğün yeri seçimine etki eden kriterleri, düğün turizminin arz unsurlarından biri olan düğün sağlayıcıları tarafından belirlemeyi amaçlamaktadır. Belirlenen amaç doğrultusunda Hatay’ın düğün turizmi kapsamında düğün yeri seçimini etkileyen kriterler, en çok karşılaşılan sorunlar, düğün turizmi algıları, Hatay’da düğün pazarının durumu ve önerileri hakkında bilgi edinebilmek için düğün sağlayıcıları olan düğün salonları, düğün organizatörleri, konaklama işletmesi ve seyahat acentaları ile gözlemler, mülakatlar gerçekleştirilmiştir.

Yapılan mülakatlar sonucu, düğün salonlarını genellikle orta gelir düzeyi ve altındaki gelir düzeylerine sahip olan kişiler ve davetli sayısının fazla olduğu ve içerik yönünden zayıf kalan etkinlikler olduğu, reklam ve tanıtımlarının olmadığı veya olanlarında yetersiz olduğu, işletenlerin gelir getirici etkisinden dolayı bu işi yaptıkları sonucuna ulaşılmıştır. Dügüün organizatörleri ve konaklama işletmeleri tercih eden çiftlerin genellikle orta düzey ve üzerinde gelir 
düzeyine sahip olan ve genellikle çalışan çiftlere veya başka yerden gelmiş Hatay'a yerleşmiş fazla çevresi olmayan katılımcı sayısının az olduğu organizasyonlar gerçekleştirmektedir. Ana amaçları düğün sahiplerinin sorumluluklarını hafifletmek, alternatifler sunmak, istek ve görüşlerine göre etkinliği düzenlemek ve stresin olmadığı öncesinde ve sonrasında bir düğün gerçekleştirmeye çalışmakta ve düğün dışında ise, kına gecesi, nişan, evlenme teklifi, doğum günleri vb. etkinlikleri düzenlemektedirler. Özellikle İskenderun, Samandağ ve Arsuz'da yer alan konaklama ișletmeleri deniz kenarlarında olduklarından ve dış çekim gibi hizmetler vermekte, organizasyon şirketleri ile de iş birliği yapmanın yanı sıra, balayı pazarına da hizmet vermekte oldukları, konaklama işletmesi açısından sezonu uzatıcı etkisi olduğu ve konaklama işletmeleri için önemli bir gelir sağladığı sonucuna ulaşılmıştır. Seyahat acentaları genellikle 45 yaş ve üzeri çiftler balayı, yıldönümü gibi özel günlerinde tatile gitmek isteyen kişiler acentaların düğün turizmi ile ilgili müşteri profilini oluşturduğunu, bu kişiler yoğun olarak çalışan ve interneti çok etkin bir şekilde kullanmadıkları için ve genellikle uğraşmamak, acentayı kendilerine garanti olarak gördükleri için tercih ettikleri sonucuna ulaşılmıştır.

Araştırmada sonuç olarak ise, Hatay’ın iklim koşulları, kültürel yapısı, doğal çekicilikleri, hava, kara ve deniz yolu ulaşımının olması, Ortadoğu'ya açılan bir kapı olarak anılması, medeniyetler şehri olarak nitelendirilmesi, alt yapı imkânları yapılan mülakatlar ve araştırmalar sonucu düğün turizmi açısından oldukça elverişli olduğu gözlemlenmiştir. Düğün salonları ile ilgili olarak iç pazarda önemli bir yere sahip olduklarını fakat dış pazar olarak bakıldığında Hatay’ın Arap bir nüfusa sahip olmasından dolayı Arap kültürüne yabancılık çekmeyeceği ve Arap pazarının önemli olduğunu, Arap ülkelerinde tanıtım ve reklam çalışmaları yapıldığ 1 takdirde önemli bir düğün destinasyonu olacağı; bu konuda yapılabilecek önemli teşvik ve yasal düzenlemeler ile Hatay’ın kültürel birikimi sayesinde gerekli yatırımlar ve tanıtım çalışmaları yapıldığında önemli bir düğün destinasyonu olabileceği ön görülmektedir. Ayrıca İskenderun, Samandağ ve Arsuz İlçeleri doğal güzellikleri ve deniz kenarındaki konaklama işletmeleri nedeniyle düğün turizmi kapsamında öncelik verilmesi, düğün destinasyonu olarak Kıbrıs gibi Akdeniz'de düğün destinasyonu olarak bir marka olabileceği ön görülmektedir. Hatay’a hava, kara ve deniz ulaşımının olması avantaj sağlamaktadır. Hatay’da düğün turizmini geliştirilmesi için düğün turizmi ile ilgili yasal düzenlemelerin yapılması, alt yapı eksikliklerinin giderilmesi, farklı dillerde tanıtım yapılması, turizmin yerel paydaşların bir araya gelerek ortak hareket etmesi önerilmektedir. 


\section{KAYNAKÇA}

Adler, H. and Chienm, T. (2004). The wedding business: a method to boost and beverage revenues in hotels. Journal of Foodservice Business Research, 7(1), pp.117-125.

Aziz, A. (2011). Sosyal bilimlerde araştırma yöntemleri ve teknikleri: araştırma süreci ve tasarımı, veri toplama teknikleri, interneti kullanma, anket hazırlama, içerik ve söylem çözümlemesi, raporlaştırma. Nobel Yayınları. Ankara.

Bertella, G. (2017). The Emergence of Tuscany as a Wedding Destination: the Role of Local Wedding Planners. Tourism Planning \& Development, 14(1), 1-14.

Ersöz, B. (2019). Düğün Yeri Seçimine Etki Eden Faktörlerin Belirlenmesi: Hatay Örneği, Yükseklisans Tezi, İskenderun Teknik Üniversitesi, Sosyal Bilimler Enstitüsü, Hatay.

Getz, D. (2008). Event Tourism: Definition, Evolution and Research. Tourism Management, 29(3), 403-428.

Karasar, N. (2005). Bilimsel Araştırma Yöntemleri. 14. Baskı. Nobel Yayın Dağıtım. Ankara.

Khodvhaeva, V. (2016). Internshıp Report: Weddıng Tourısm In Portugal, Masters in Tourism and Communication, Instituto De Geografia e Ordenamento Do Territorio, Lisbon, Portugal.

Kim, S. and Agrusa, J. (2005). The positioning of overseas honeymoon destinations. Annals of Tourism Research, 32(4), pp.887-904.

Kim, Y., ve Kim, D. (2013). An İnvestigation of Korean Wedding İndustry And Suggestions For İts Future Development From The Tourism Perspective. South Asian Journal of Tourism and Heritage, 6(1), 11-20.

Kiper, T. (2006). Safranbolu Yörük Köyü Peyzaj Potansiyelinin Kırsal Turizm Açısından Değerlendirilmesi, Ankara Üniversitesi, Fen Bilimleri Enstitüsü, Peyzaj Mimarlığı Anabilim dalı (Doktora Tezi). Ankara.

Major, B., McLeay, F., ve Waine, D. (2010). Perfect Weddings Abroad. Journal of Vacation Marketing, 16(3), $249-262$.

Mintel (2010). Weddings and Honeymoons Abroad - UK - URL: http://oxygen.mintel.com/display/479945/, Son Erişim Tarihi: 21.04.2019.

Moira, P., Mylonopoulos, D., ve Parthenis, S. (2011). A Sociological Approach To Wedding Travel. A Case Study: Honeymooners İn Ioannina. The Internatıonal Sounds and Tastes of Tourısm Educatıon, 20-22 Ekim, Greece, $24-$ 33.

Özsoy, Y. (1970). Ĕgitimde Öğrencileri Tanıma Teknikleri, Ulucanlar Matbaası, Ankara.

Rogerson, J. M., ve Wolfaardt, Z. (2016). Wedding Tourism in South Africa: An Exploratory Analysis. African Journal of Hospitality, Tourism and Leisure, 4(2), 1-6.

Seebaluck, N. V., Munhurrun, P. R., Naidoo, P., ve Rughoonauth, P. (2015). An Analysis of The Push and Pull Motives for Choosing Mauritius as "The” Wedding Destination. Procedia-Social and Behavioral Sciences, 175, 201-209.

Vidauskaite, R. (2015). Destination Branding Through Wedding Tourism: The Case of The Caribbean, Master Thesis, Faculty of Economics University of Ljubljana, Slovenia.

Winchester, M., Winchester, T., Alvey, F. ve Adams, H. (2011). Seeking Romance And A Once in A Life-Time Experience: Considering Attributes That Attract Honeymooners to Destinations. Paper presented at Australia and New Zealand Marketing Academy Conference, Perth. 